\title{
BIMBINGAN KELOMPOK MODEL PERMAINAN BELAJAR BERSIKAP UNTUK MENINGKATKAN KEMAMPUAN PENYESUAIAN DIRI DI SEKOLAH SISWA
}

\author{
Dinar Mahdalena Leksana \\ Program Studi PIAUD, Fakultas Agama Islam, Universitas Islam \\ Lamongan \\ Jl.Veteran No. 53 A Lamongan 62213 \\ Telp. 0322-324706 / 0822-4444-8142 \\ E-mail: chealeksa.ca@gmail.com
}

\begin{abstract}
The goal of this research was to test the effectiveness of using group guidance service with learn to behave game to increase the ability of self adjustment at school. This research was conducted by pre-test post-test one group design. The subject of this research were eight students of $7^{\text {th }}$ graders at MTs Darrul Ma'arif Payaman, with low score of the ability of self adjustment at school. Data analysis technique used in this research was Wilcoxon's signed rank test. It was found that there was a significant difference between the ability of self adjustment at school score before and after treatment. Based on the Wilcoxon test it was found that $T$ count $=0, N=8$ with 0,05 significant level so T table $=4$. It means $T$ count $<T$ table $(0<4)$. So hypothesis of this research was accepted. It can be concluded that group guidance service with learn to behave game was an effective approach to help students to increase the ability of self adjustment at school.
\end{abstract}

Keywords : Group guidance, The ability of self adjustment at school.

\section{Pendahuluan}

Pada hakikatnya pendidikan merupakan usaha sadar untuk pengembangan kepribadian yang belangsung seumur hidup. Pendidikan juga bermakna proses membantu individu baik jasmani dan rohani ke arah terbentuknya kepribadian yang optimal dari setiap peserta didik sesuai dengan potensi dan karakteristiknya masing-masing, dimana peserta didik merupakan pribadi-pribadi yang unik dengan segala karakteristiknya. Sebagai individu yang dinamis dan berada dalam proses perkembangan, siswa memiliki kebutuhan dan dinamika dalam interaksi dengan lingkungannya.

Hal ini tidak lepas dari hakekat manusia sebagai makhluk sosial bahwasanya setiap individu memerlukan orang lain dalam kehidupannya. Untuk dapat berhubungan dengan orang lain secara baik, individu dituntut mampu beradaptasi (menyesuaikan diri) dengan lingkungannya. Karena setiap individu 
memiliki kemampuan yang berbeda untuk berinteraksi dengan lingkungannya. Beberapa individu mampu menyesuaiakan diri dengan cepat dan baik dengan lingkungan barunya sehingga tidak akan mengalami hambatan dalam pergaulan.

Dengan penyesuaian diri akan menumbuhkan rasa optimis dan positif yang dapat mendorong anak berbuat lebih banyak dan teliti sehingga kemungkinan berhasil akan diperolehnya. Sebaliknya individu yang kurang bisa menyesuaiakan diri, berpeluang untuk mengalami kegagalan dalam proses pendidikan dan pembelajarannya. Individu yang kurang mampu menyesuaikan diri terhadap lingkungannya akan mengalami perasaan tertekan karena merasa dikucilkan dari pergaulan. Hal ini sesuai dengan Panut Panuju ${ }^{1}$ “individu yang tidak dapat menyesuaikan diri akan memiliki kekurangan-kekurangan sehingga akan merasa terasing dan terisolir dari lingkungan masyarakat dimana dia hidup".

Permasalahan penyesuaian diri di sekolah mungkin akan timbul ketika remaja mulai memasuki jenjanng sekolah yang baru. Mereka mungkin mengalami permasalahan penyesuaian diri dengan guru-guru, teman dan mata pelajaran yang baru. Perpindahan ke masyarakat yang baru seringkali menyebabkan remaja mengalami kesulitan dalam membentuk persahabatan dan hubungan sosial yang baru Sunarto ${ }^{2}$.

Berdasarkan hasil wawancara dengan guru BK di MTs Darrul Ma'arif Payaman, diketahui bahwa siswa kelas VII seringkali mengalami permasalahan diakibatkan kurangnya kemampuan mereka dalam menyesuaikan diri dengan lingkungan sekolahnya yang baru. Beberapa siswa sering bertengkar karena masalah sepele, menunjukkan sikap senang mengganggu serta cenderung menang sendiri dan menyalahkan temannya. Beberapa siswa cenderung menyendiri dan sulit untuk membentuk hubungan persahabatan dengan teman-teman barunya.

Hal ini senada dengan yang disampaikan dalam bukunya Sunarto ${ }^{3}$ menyatakan bahwa salah satu upaya yang dapat dilakukan untuk memperlancar

\footnotetext{
${ }^{1}$ Panut panuju dan Ida Umami, Psikologi Remaja. Yogyakarta: Tiara Wacana, 2005, 37.

${ }^{2}$ Sunarto dan Hartono Agung, Perkembangan Peserta Didik, Jakarta: Rieneka Cipta, 1999, 239.

${ }^{3}$ Ibid 239
} 
proses penyesuaian diri remaja khususnya di sekolah adalah dengan pelaksanaan progam bimbingan dan penyuluhan yang sebaik-baiknya.

Pendapat ini juga didukung dengan keberadaan Undang-undang Nomor 20 Tahun 2003 tentang Sistem Pendidikan Nasional tentang pelaksanaan layanan Bimbingan dan Konseling di sekolah, yang merupakan bagian dari system pendidikan nasional.

Salah satu layanan yang dapat diterapkan dalam membantu pemecahan permasalahan siswa adalah layanan bimbingan kelompok. Aktifitas kelompok diarahkan untuk memperbaiki dan mengembangkan pemahaman diri dan lingkungan, penyesuaian diri serta pengembangan diri Juntika ${ }^{4}$

Bimbingan kelompok merupakan suatu pemberian bantuan (bimbingan) yang diberikan kepada peserta didik melalui kegiatan kelompok. Dalam layanan bimbingan kelompok, aktivitas dan dinamika kelompok harus diwujudkan untuk membahas berbagai hal yang berguna bagi pengembangan dan pemecahan masalah siswa yang menjadi peserta layanan. Senada dengan yang diungkapkan oleh beberapa tokoh bahwa layanan bimbingan kelompok secara umum bertujuan untuk pengembangan kemampuan bersosialisasi, khususnya kemampuan berkomunikasi peserta layanan (siswa). Secara lebih khusus, layanan bimbingan kelompok bertujuan untuk mendorong pengembangan perasaan, pikiran, persepsi, wawasan dan sikap yang menunjang perwujudan tingkah laku yang lebih efektif, yakni peningkatan kemampuan berkomunikasi baik verbal maupun nonverbal para siswa Tohirin ${ }^{5}$

Ada beberapa teknik yang dapat diterapkan dalam layanan bimbingan kelompok, salah satunya adalah teknik umum dan permainan kelompok Tohirin ${ }^{6}$. Permainan dapat dijadikan sebagai salah satu teknik dalam layanan bimbingan kelompok baik sebagai pelengkap teknik-teknik yang lain maupun sebagai suatu

\footnotetext{
${ }^{4}$ Achmad Juntika Nurihsan,. Bimbingan Dan Konseling Dalam Berbagai Latat Kehidupan. (Bandung: Refika Aditama. 2006), 23.

5 Tohirin.. Bimbingan Dan Konseling Di Sekolah Dan Madrasah (Berbasis Integrasi). (Jakarta: Raja Grafindo Persada, 2007), 172.

${ }^{6}$ Ibid 173
} 
teknik tersendiri yang merupakan wahana pemuat materi pembinaan atau materi layanan tertentu.

Karena dengan permainan peserta didik dapat melampiaskan dorongandorongan emosinya sehingga tercipta perasaan lega dan puas. Suasana menyenangkan dan santai yang tercipta selama permainan berlangsung akan menimbulkan suatu pengalaman tersendiri bagi peserta didik yang kemudian akan direnungkan untuk menyadari perasaan dan reaksi-reaksi mereka. Dinamika kelompok yang tercipta juga akan mendorong peserta didik untuk mampu melakukan interaksi sosial sehingga peserta didik akan mampu menyesuaikan diri secara baik dan wajar dalam lingkungan sosialnya.

Berdasarkan latar belakang di atas maka peneliti akan melakukan penelitian untuk menguji penggunaan bimbingan kelompok model permaianan belajar bersikap untuk meningkatkan kemampuan penyesuaian diri siswa kelas VII MTs Darrul Ma’arif, Payaman.

\section{Penyesuaian Diri}

Menurut Sunarto ${ }^{7}$ penyesuaian diri adalah usaha manusia untuk mencapai keharmonisan pada diri sendiri dan pada lingkungannya.

Sedangkan menurut Sofyan Willis ${ }^{8}$ penyesuaian diri adalah kemampuan seseorang untuk hidup dan bergaul secara wajar terhadap lingkungannya, sehingga ia merasa puas terhadap dirinya dan terhadap lingkungannya.

Berdasarkan pendapat di atas dapat disimpulkan bahwa penyesuaian diri adalah usaha atau kemampuan seseorang untuk hidup dan bergaul secara wajar terhadap lingkungannya sehingga ia memperoleh keharmonisan dan kepuasan terhadap dirinya maupun lingkungannya.

Berkaitan dengan bentuk-bentuk penyesuaian diri maka di paparkan oleh Sri Rumini ${ }^{9}$, bentuk-bentuk penyesuaian diri adalah sebagai berikut :

\footnotetext{
${ }^{7}$ Ibid 222.

${ }^{8}$ Willis, Sofyan, Remaja Dan Masalahnya, (Bandung: Alfabeta. 2005), 55.
} 
a. Penyesuaian diri yang positif

1) Tidak menunjukkan adanya ketegangan emosional

2) Tidak menunjukkan adanya mekanisme psikologis

3) Tidak adanya frustasi pribadi

4) Memiliki pertimbangan rasional dan pengarahan diri

5) Mampu dalam belajar

6) Menghargai pengalaman

7) Bersikap realistik dan obyektif

b. Penyesuaian diri yang salah

1) Reaksi bertahan diri ialah suatu usaha bahwa dirinya tidak mengalami kegagalan, meskipun sebenarnya mengalami kegagalan atau kekecewaan. Bentuk reaksi bertahan itu antara lain :

a) Rasionalisasi yaitu suatu usaha bertahan dengan mencari alasan yang masuk akal

b) Represi yaitu suatu usaha menekan atau melupakan hal yang tidak menyenangkan

c) Proyeksi yaitu suatu usaha memantulkan ke pihak lain dengan alasan yang dapat diterima

2) Reaksi menyerang ialah suatu usaha untuk menutupi kegagalan atau tidak mau menyadari kegagalan dengan tingkah laku yang bersifat menyerang. Reaksi yang muncul antara lain :

a) Senang membenarkan diri sendiri

b) Senang mengganggu orang lain

c) Menggertak dengan ucapan dan perbuatan

d) Menunjukkan sikap permusuhan secara terbuka

e) Menunjukkan sikap merusak

f) Keras kepala dan balas dendam

g) Marah secara sadis

${ }^{9}$ Sri Rumini,dan Sundari Siti, Prekembangan Anak Dan Remaja. (Jakarta: Rineka Cipta, 2004), 184 
3) Reaksi melarikan diri ialah usaha melarikan diri dari suatu situasi yang menimbulkan kegagalan, reaksi itu tampak dalam bentuk mereaksikan keinginan yang tidak dicapai antara lain :

a) Banyak tidur

b) Minum minuman keras

c) Pecandu ganja dan narkotika

d) Regresi atau kembali pada tingkat perkembangan yang lalu

Sedangkan menurut Sunarto $^{10}$, bentuk-bentuk penyesuaian diri adalah :

a. Penyesuaian diri secara positif yaitu berupa tidak ada ketegangan secara emosional, tidak terjadi frustasi, menggunakan pertimbangan rasional, realistik dan obyektif

b. Penyesuaian diri yang salah yaitu berupa reaksi bertahan, menyerang dan melarikan diri

Berdasarkan pendapat di atas, maka bentuk-bentuk penyesuaian diri adalah :

a. Penyesuaian diri secara positif yaitu berupa tidak ada ketegangan secara emosional, tidak terjadi frustasi, menggunakan pertimbangan rasional, realistik dan obyektif

Penyesuaian diri yang salah yaitu berupa reaksi bertahan, menyerang dan melarikan diri

\section{Bimbingan Kelompok}

Tohirin ${ }^{11}$ menyatakan bahwa layanan bimbingan kelompok merupakan suatu cara memberikan bantuan (bimbingan) kepada individu (siswa) melalui kegiatan kelompok. Dalam layanan bimbingan kelompok, aktivitas dan dinamika kelompok harus diwujudkan untuk membahas berbagai hal yang berguna bagi pengembangan atau pemecahan permasalahan individu yang menjadi peserta layanan.

\footnotetext{
${ }^{10}$ Ibid 242

${ }^{11}$ Ibid 170
} 
Keunggulan bimbingan kelompok menurut Prayitno dalam Nursalim 12 meliputi :

a. Menyangkut aspek ekonomis/ efisiensi, yaitu dengan adanya kelompok akan semakin banyak orang yang dibantu sehingga relatif membutuhklan waktu yang lebih cepat

b. Dengan adanya interaksi yang intensif dan dinamis diharapkan tujuan bimbingan dapat tercapai secara lebih mantap

c. Dinamika yang terjadi dalam kelompok mencerminkan suasana kehidupan nyata yang dapat dijumpai di masyarakat

Alasan penggunaan bimbingan kelompok antara lain :

a. Adanya tuntukan kebutuhan seseorang akan suasana kelompok

b. Banyaknya siswa yang mengalami masalah

c. Adanya suatu masalah yang harus dipecahkan melalui kelompok yaitu dengan mesdiskusikannya bersama-sama dalam kelompok

d. Untuk menolong individu agar lebih baik dalam hubungan sosial dan memperbaiki sifat-sifat pribadinya

e. Untuk mengatasi masalah-masalah yang sama sehingga bisa dilakukan bimbingan secara bersama-sama

Secara umum layanan bimbingan kelompok bertujuan untuk pengembangan kemampuan bersosialisasi, khususnya kemampuan berkomunikasi siswa. Secara lebih khusus, layanan bimbingan kelompok bertujuan untuk mendorong pengembangan perasaan, pikiran, persepsi, wawasan dan sikap yang menunjang perwujudan tingkah laku yang lebih efektif, yakni peningkatan kemampuan berkomunikasi baik verbal maupun nonverbal para siswa Tohirin ${ }^{13}$

Menurut Jumhur dan Surya dalam Nursalim ${ }^{14}$ teknik-teknik bimbingan meliputi : home room, karya wisata, diskusi kelompok, kegiatan kelompok, remidial teaching, psikodrama, sosiodrama, bermain dan kerja kelompok.

\footnotetext{
12 Nursalim, Mochamad dan Suradi, Layanan Bimbingna Dan Konseling, (Surabaya:
} UNESA University Press, 2002), 55.

\footnotetext{
${ }^{13}$ Ibid 172

${ }^{14}$ Ibid 57
} 
Permainan dapat dijadikan sebagai salah satu teknik dalam layanan bimbingan kelompok baik sebagai selingan maupun sebagai wahana yang memuat materi pembinaan atau materi layanan tertentu.

Permainan kelompok yang efektif dan dapat dijadikan sebagai teknik dalam layanan bimbingan kelompok harus memenuhi ciri-ciri sebagai berikut :
a. Sederhana
b. Menggembirakan
c. Menimbulkan suasana santai dan tidak melelahkan
d. Meningkatkan keakraban
e. Diikuti oleh semua anggota kelompok

\section{Bimbingan Kelompok Model Permainan Belajar Bersikap}

Bimbingan kelompok model permainan belajar bersikap adalah suatu kegiatan bimbingan yang diberikan kepada sekelompok individu atau murid untuk membantu menyelesaikan masalah baik itu masalah pendidikan atau pengajaran, pekerjaan, situasi sosial, dan sebagainya dengan menggunakan permainan belajar bersikap yang berguna untuk merangsang dan membina pengalaman-pengalaman pribadi dan sebagai kelompok.

Permainan dilakukan dalam suasana yang rileks dan menyenangkan, sehingga peserta akan mendapatkan suatu pengalaman. Kemudian mereka diajak untuk menghayati pengalaman tersebut kemudian merenungkannya sehingga mereka menyadari perasaan dan reaksi-reaksi fisik mereka. Setelah itu, mereka diajak untuk mengungkapkan hal-hal yang dialami waktu latihan atau permainan berlangsung. Pengalaman yang diperoleh kemudian diolah kelompok bersama pembimbing, dengan cara mendiskusikannya dan menarik kesimpulan.

Prosedur pelaksanaan secara umum :

- Tahap permulaan

Fasilitator mengusulkan suatu permainan/ latihan, menjelaskan cara permain serta peraturan permainan. Ia harus memastikan bahwa setiap peserta sudah mengerti permainan yang akan dijalani.

- Tahap bermain 
Fasilitator tidak ikut berperan. Hasil dari permainan/ latihan yang sedang dijalankan merupakan tanggung jawab kelompok dan masing-masing anggota kelompok. Merekalah yang menentukan proses bermain. Fasilitator mengamati proses bermain supaya dapat dibahas bersama kelompok setelah permainan berakhir.

- Tahap evaluasi

Tahap ini sangat penting dan tidak boleh dilewatkan begitu saja. Setelah permainan selesai dan dievaluasi, arti dan makna dari permainan/ latihan yang baru dilakukan akan jelas bagi peserta.

Fasilitator mendorong para peserta untuk memikirkan pengalamanpengalaman mereka yang baru dan memberanikan mereka untuk mengungkapkan perasaannya. Akhirnya, fasilitator dapat menyimpulkan dan menunjukkan hasil ataupun dasar yang penting dari latihan yang telah dilakukan.

Teknik permainan yang digunakan antara lain :

a. Tebak suara teman

Tata cara permainan :

1. Posisi duduk peserta dibuat dalam bentuk lingkaran

2. Pemandu menunjuk salah seorang peserta untuk menjadi petugas

3. Petugas tersebut matanya di tutup kain penutup agar tidak dapat melihat peserta yang akan di tebak. Lalu didatangi oleh salah seorang peserta

4. Petugas lalu bertanya kepada peserta yang ada di hadapannya. Pertanyaan yang diajukan boleh di sekitar ciri-ciri fisik

5. Akhir dari permainan ini apabila orang yang ditanya tertebak namanya, lalu bergantian. Jika tidak tertebak, dia akan jadi petugas lagi

b. Bermain api

Tata cara permainan : 
1. Peserta dibagi menjadi kelompok yang kecil, berbaris berderet dan menjaga jarak kurang lebih 3 meter setiap orangnya

2. Setiap peserta diberi satu biji korek api

3. Nyala api dimulai dari pemandu.

4. Api orang pertama diberikan kepada orang kedua dengan cara mendekat kepada orang kedua yang sudah siap memegng biji korek api sendiri.

5. Demikian seterusnya

6. Orang terakhir harus berjalan menuju lilin di epan untuk dinyalakan. Peserta yang lebih dulu menyalakan lilin, berarti kelompok tersebut menjadi pemenang

c. Berdiri di atas koran

Tata cara permainan :

1. Peserta dibagi menjadi kelompok yang kecil 2-3 orang yang sejenis kelamin

2. Setiap kelompok diberi selembar koran bekas

3. Setiap kelompok berdiri di atas koran. Mereka harus bekerjasama merobek koran yang tidak terinjak

4. Kaki tidak boleh menyentuh lantai, harus selalu berada di atas kertas koran

5. Pemenangnya adalah kelompok yang berhasil menyisakan kertas koran sekecil mungkin tanpa jatuh ke lantai

d. Gambar berlanjut

Tata cara permainan :

1. Peserta dibagi menjadi kelompok yang kecil, berdiri berderet dengan posisi masing-masing peserta menghadap ke depan

2. Pemandu membagikan spidol kepada setiap peserta kelompok dan satu lembar kertas manila kepada setiap kelompok

3. Permainan diawali dari orang yang berdiri paling belakang. Orang ini membuat goresan/ garis maksimal 2 sekehendak hatinya 
4. Kertas lalu diberikan kepada orang kedua yang ada didepannya yang kemudian melanjutkan dengan maksimal dua garis juga

5. demikian seterusnya hingga orang terakhir yang berdiri paling depan. Pemenangnya adalah mereka yang paling cepat selesai namun bentuk gambarnya jelas

e. Lipat melipat bersama

Tata cara permainan :

1. Peserta dibagi menjadi kelompok yang kecil, membentuk barisan berderet

2. Orang pertama dari setiap kelompok mendapatkan selembar kertas sebagai bahan yang akan dilipat

3. Ketika pemandu memberi aba-aba mulai, peserta pertama baru diperbolehkan melipat. Masing-masing peserta hanya diperbolehkan maksimal 2 lipatan

4. Kertas lipatan diberikan kepada orang berikutnya, kemudian dilanjutkan lipatannya

5. Permaian berlanjut sampai orang terakhir. Pemenangnya apabila kelompok mampu menyelesaiak pekerjaannya denga cepat dan hasil lipatan terlihat bentuknya

f. Menyusun bersama

Tata cara permainan :

1. Peserta dibagi menjadi kelompok yang kecil

2. Setiap kelmpok mendapatkan 1 set potongan gambar tertentu. Masing-masing peserta mendapatkan potongan gambar paling sedikit satu potong

3. Potongan gambar masing-masing peserta harus dibawa sendirisendiri dan tidak boleh ditukarkan

4. Cara menggabungkan potongan kertas harus dilakukan sendirisendiri

5. Kelompok yang paling cepat dan benar membentuk gambar adalah pemenangnya 
g. Pesan gambar berantai

Tata cara permainan :

1. Peserta dibagi menjadi kelompok yang kecil, berbaris berderet memanjang. Boleh berdiri atau duduk

2. Setiap peserta mendapatkan kertas dan alat tulis. Orang pertama dalam setiap kelompok membuat seluruh lukisan apa saja menurut gagasannya

3. Apabila lukisan tersebut selesai, kemudian ditunjukkan kepada anggota kelompok dengan batasan waktu yang sangat singkat dan hanya ditunjukkan sekali

4. Peserta kedua mengulang gambar yang sama yang dilihatnya

5. Demikian seterusnya hingga orang terakhir

6. Pemenangnya adalah kelompok yang dapat melakukan hal tersebut dengan cepat dan tepat

h. Pindah anggur berantai

Tata cara permainan :

1. Peserta dibagi menjadi kelompok yang kecil, berbaris berderet di belakang meja

2. Buah anggur dan piring diolesi minyak terlebih dahulu

3. Pembagian pralatan

Orang pertama mendapatkan piring, sepasang sumpit dcan 3 buah anggur. Orang kedua pirng dan sepasang sumpit, seangkan orang ketiga hanya piring saja

4. Proses permainan

Orang pertama mulai memindahkan buah anggur satu persatu dengan menggunakan sumpit dan diberikan ke piring orang kedua. Lalu diteruskan orang kedua kepiring orang ketiga

Metode Maka penelitian ini termasuk penelitian kuantitatif dan menggunakan pendekatan eksperimen yaitu penelitian yang dimasudkan untuk mengetahui ada tidaknya akibat atau pengaruh dari sesuatu yang dikenakan pada subyek penelitian. 
Dalam penelitian ini menggunakan rancangan penelitian preksperimental design dengan model pretest-post test one group design, yaitu eksperimen yang dilakukan pada satu kelompok saja tanpa kelompok pembanding. Dengan tujuan untuk mengetahui perbedaan skor kemampuan penyesuaian diri di sekolah dengan menggunakan layanan bimbingan kelompok, dengan mengukur tingkat penyesuaian diri siswa di sekolah sebelum perlakuan (pre-test) dan setelah diberi perlakuan dalam jangka waktu tertentu (post-test).

Gambarl 1

Pre-test and Post-test One Group Design

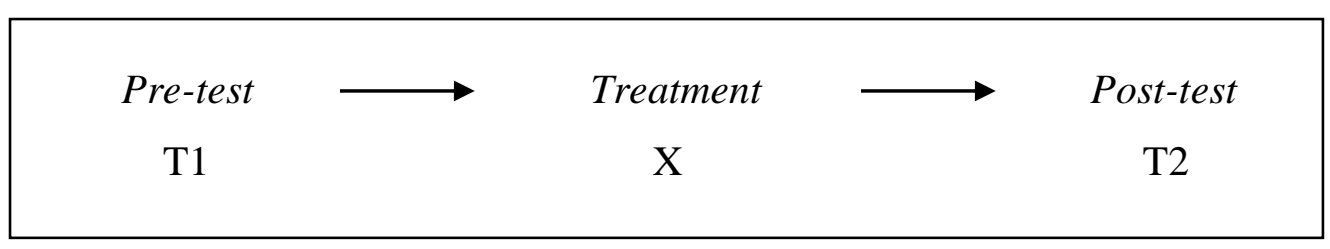

Keterangan :

T1 : Tes Awal (Pre-Test) sebelum pemberian perlakuan

$\mathrm{X}$ : Treatment (perlakuan) disini adalah pemberian bimbingan kelompok model permainan belajar bersikap

T2 : Tes Akhir (Post-Test) setelah pemberian perlakuan

a. Prosedur Penelitian

1. Pre test

Menentukan siswa yang mempunyai tingkat kemampuan penyesuaian diri yang rendah menggunakan angket yang sudah diuji validitas dan reliabilitas. Angket diberikan pada siswa kelas VII SMPN 1 Diwek. Maksud pemberian pre test adalah untuk mengetahui siswa yang memiliki tingkat kemampuan penyesuaian diri yang rendah (menemukan subyek penelitian). Setelah angket diberikan dilakukan penghitungan skor yang telah ditentukan.

2. Perlakuan 
Setelah diketahui siswa yang memiliki tingkat penyesuaian diri yang rendah, maka diberikan perlakuan bimbingan kelompok model permainan belajar bersikap. Adapun permainan yang diberikan adalah:
a. Tebak suara teman
b. Bermain api
c. Berdiri di atas koran
d. Gambar berlanjut
e. Lipat melipat bersama
f. Menyusun bersama
g. Pesan gambar berantai
h. Pindah anggur berantai

\section{Post test}

Melakukan post test dengan disebarkannya kembali angket untuk mengukur kemampuan penyesuaian diri di sekolah setelah diberikan perlakuan bimbingan kelompok model permainan belajar bersikap.

2. Tahap Analisis Data

Analisi data yang dipakai Adalah Analisis Statistik dengan menggunakan Uji Jenjang Wilcoxcon

3. Tahap Pembahasan

Tahap ini berisi tentang pembahasan hal-hal yang dianggap penting dalam penelitian

Dalam penelitian ini menggunakan angket yang disusun berdasarkan kisi-kisi variabel penelitian. Adapun kisi-kisi dari variabel penelitian dapat dilihat pada table dibawah ini;

\section{Tabel 3.1}

Kisi-kisi Angket Kemampuan

Penyesuaian Diri Di Sekolah

\begin{tabular}{|l|l|l|l|}
\hline Variabel & Indikator & Jumlah & Butir Soal \\
\hline
\end{tabular}




\begin{tabular}{|c|c|c|c|c|}
\hline & & Item & + & - \\
\hline \multirow[t]{7}{*}{$\begin{array}{c}\text { Penyasuaian } \\
\text { diri }\end{array}$} & $\begin{array}{l}\text { a. Dapat mengendalikan } \\
\text { pikiran, angan-angan, } \\
\text { keinginan, dorongan emosi } \\
\text { dan tingkah laku }\end{array}$ & 8 & 13,22 & $\begin{array}{c}2,3,12 \\
31,33 \\
34\end{array}$ \\
\hline & $\begin{array}{l}\text { b. Mengetahui, menerima dan } \\
\text { memperbaiki kelemahan } \\
\text { secara rasional }\end{array}$ & 6 & $\begin{array}{c}1,15 \\
32\end{array}$ & $\begin{array}{c}14,23 \\
24\end{array}$ \\
\hline & $\begin{array}{l}\text { c. } \text { Mampu mengatasi } \\
\text { perubahan diri dan social } \\
\text { secara fleksibel }\end{array}$ & 5 & 35,37 & $\begin{array}{c}5,16 \\
36\end{array}$ \\
\hline & $\begin{array}{l}\text { d. Dapat mencapai kepuasan } \\
\text { psikis }\end{array}$ & 7 & $\begin{array}{c}4,18 \\
39\end{array}$ & $\begin{array}{l}6,17 \\
38,40\end{array}$ \\
\hline & $\begin{array}{l}\text { e. Dapat mencapai efisiensi } \\
\text { kerja }\end{array}$ & 10 & $\begin{array}{l}7,25 \\
42,49\end{array}$ & $\begin{array}{l}10,19 \\
20,26 \\
43,47\end{array}$ \\
\hline & $\begin{array}{l}\text { f. Menunjukkan penerimaan } \\
\text { social dalam bergaul }\end{array}$ & 8 & $\begin{array}{l}9,21 \\
27,44\end{array}$ & $\begin{array}{l}8,28 \\
46,50\end{array}$ \\
\hline & $\begin{array}{l}\text { g. Tidak menampakkan gejala } \\
\text { fisik yang tidak sehat }\end{array}$ & 6 & 11,41 & $\begin{array}{l}29,30 \\
45,48\end{array}$ \\
\hline & Jumlah & & 50 & \\
\hline
\end{tabular}

Dalam penelitian ini metode analisis data yang digunakan adalah analisis statistik. Hal ini disebabkan data yang dikumpulkan berupa angka atau bilangan (penelitian kuantitatif). Karena data yang disajikan berbentuk ordinal dan berdistribusi normal yang artinya subyek dalam penelitian ini kurang dari 25 , yaitu terdapat 8 subyek $(\mathrm{N}=8)$ yang akan mendapatkan perlakuan. Maka dalam penelitian ini digunakan teknik analisis data statistik non parametrik. 
Menurut Siegel ${ }^{15}$ "Jika sampelnya kecil, hanya tes non parametrik yang bisa digunakan".

Teknik analisis non parametrik yang digunakan untuk menguji hipotesis dalam penelitian ini adalah uji Jenjang Wilcoxon yang merupakan penyempurnaan dari uji tanda (Sign test). Hal ini disebabkan penelitian ini sampel-sampelnya saling berkorelasi dan datanya berbentuk ordinal (data yang berupa peringkat atau ranking yaitu rendah dan tinggi). Menurut Martini $^{16}$ Uji Jenjang Wilcoxon ini digunakan untuk menguji hipotesis komparatif dua sampel yang berkorelasi bila datanya berbentuk ordinal (berjenjang). Dalam Uji Jenjang Wilcoxon, bukan saja tanda (positif negatif) besarnya beda atau selisih(X-Y) juga diperhatikan .

Adapun prosedur Uji Jenjang Wilcoxon adalah sebagai berikut :

1. Berikan jenjang (rank) untuk tiap-tiap beda dari pasangan pengamatan $(\mathrm{Xi}-\mathrm{Yi})$ sesuai dengan besarnya dari yang terkecil sampai terbesar tanpa memperhatikan tanda dari beda itu (Nilai beda absolute). Bila ada dua atau lebih yang sama, maka jenjang untuk tiap-tiap beda itu adalah jenjang ratarata .

2. Bubuhkan tanda positif atau negatife pada jenjang untuk tiap-tiap beda sesuai dengan tanda dari beda itu. Beda $\mathrm{O}$ tidak diperhatikan .

3. Jumlahkan semua jenjang bertanda positif atau semua jenjang yang bertanda negatife tergantung dari mana yang memberikan jumlah yang lebih kecil setelah tandanya dihilangkan. Notasikan jumlah jenjang yang lebih kecil ini degnan $\mathrm{T}$

4. Bandingkan nilai $\mathrm{T}$ yang diperoleh dengan nilai $\mathrm{T}$ untuk uji jenjang beda wilcoxon

Jumlah $\mathrm{T}$ inilah yang dipakai untuk menguji hipotesis.

Ho : Tidak ada perbedaan pengaruh perlakuan

Ha : Terdapat perbedaan pengaruh perlakuan

${ }^{15}$ Sidney Siegel, Statistik Non Parametrik Untuk Ilmu Sosial, (Jakarta: Gramedia Pustaka Utama, 1990), 40.

${ }^{16}$ Martini, "Prosedur dan Prinsip-prinsip Statistika", (Surabaya,Unesa University press, 2005), 82. 


\section{Hasil dan Pembahasan}

Berdasarkan hasil Pre test diperoleh hasil terdapat 8 siswa yang memiliki sikap penyesuaian diri rendah berdasarkan kategori yang telah dibuat, dari sini peneliti memberikan perlakuan bimbingan kelompok model permainan bersikap dengan kegiatan sebagai berikut:

Berikut ini disajikan kegiatan perlakuan bimbingan kelompok model permainan belajar bersikap yang digunakan untuk meningkatkan kemampuan penyesuaian diri di sekolah pada 8 siswa yang berada pada kategori rendah.

a. Pertemuan I

Waktu

: 60 menit

Teknik permainan : Tebak suara teman

Tujuan : Membiasakan diri berkonsentrasi untuk menemukan sesuatu melalui hal-hal yang kita kenali. Belajar memberi kepercayaan kepada teman sekaligus dipercaya teman.

b. Pertemuan II

Waktu : 60 menit

Teknik permainan : Bermain api

Tujuan :Belajar melakukan suatu hal dengan penuh kehati-hatian dan pertimbangan agar tercapai tujuan.

c. Pertemuan III

Waktu $\quad: 60$ menit

Teknik permainan : Berdiri di atas koran

Tujuan : Peserta dapat melakukan pekerjaan dalam keadaan serba terbatas tapi mampu bertahan dalam kelompok yang utuh.

d. Pertemuan IV

Waktu : 60 menit

Teknik permainan: Gambar berlanjut

Tujuan : Peserta mampu memahami bahwa dalam kerja kelompok semua berperan dan saling melengkapi.

e. Pertemuan V 
Waktu : 60 menit

Teknik permainan : Lipat melipat bersama

Tujuan : Peserta dapat menghagai karya orang lain

f. Pertemuan VI

Waktu : 60 menit

Teknik permainan : Menyusun bersama

Tujuan : Peserta dapat semakin percaya diri atas kehadirannya di tengah banyak orang karena sesuatu yang ada padanya berarti bagi orang lain.

g. Pertemuan VII

Waktu : 60 menit

Teknik permainan : Pesan gambar berantai

Tujuan : Melatih nenyampaikan sebuah gagasan yang belum utuh lalu dilengkapi oleh teman yang lain, memahami hasil karya bersama yang tentu saja berbeda dengan hasil karya pribadi

h. Pertemuan VIII

Waktu : 60 menit

Teknik permainan : Pindah anggur berantai

Tujuan : Menyadari usaha dan kemampuan masing-masing pribadi yang dipadukan menjadi kekuatan tim, akhirnya membuahkan sebuah kemenangan/ keberhasilan. Melatih diri bekerja secara hati-hati karena dampaknya akan dirasakan bersama orang lain.

Setelah diberikan perlakuan seperti bimbingan kelompok model permainan bersikap, maka peneliti melakukan kegiatan post test pada ke 8 siswa tersebut yang mendapat perlakuan, guna mengetahui bagaimana hasil pemberian perlakuan terhadap siswa.

Dari hasil post test yang dilakukan diperoleh data yang berbeda dengan kegiatan pre test. Ini tergambar sari table dan histogram berikut:

Tabel 4.4

Hasil Analisis Post Test Angket Kemampuan Penyesuaian Diri di Sekolah

\begin{tabular}{|l|l|l|l|}
\hline NO & SUBJEK & SKOR & KETERANGAN \\
\hline
\end{tabular}




\begin{tabular}{|c|c|c|c|}
\hline 1 & FZ & 161 & Tinggi \\
\hline 2 & MA & 148 & Sedang \\
\hline 3 & ESN & 144 & Sedang \\
\hline 4 & ZR & 150 & Sedang \\
\hline 5 & ACA & 146 & Sedang \\
\hline 6 & EA & 163 & Tinggi \\
\hline 7 & EE & 143 & Sedang \\
\hline 8 & SDC & 147 & Sedang \\
\hline
\end{tabular}

Dari hasil post test pada tabel di atas dapat digambarkan dalam grafik sebagai berikut :

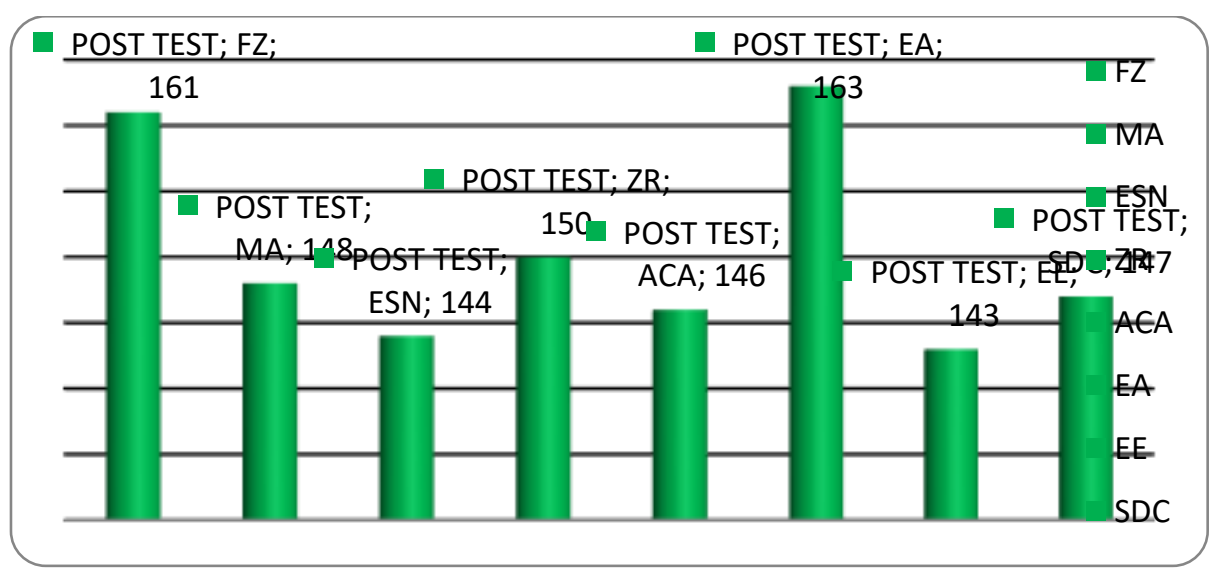

\section{Histrogram 4.2}

Hasil Analisis Post Test

Berdasarkan hasil analisi di atas menunjukkan bahwa penelitian bimbingan kelompok model permainan belajar bersikap efektif untuk meningkatkan kemampuan penyesuaian diri siswa. Ini berarti bahwa ada perbedaan yang positif mengenai kemampuan penyesuaian diri, yaitu semakin meningkatnya kemampuan penyesuaian diri siswa setelah perlakuan bimbingan kelompok model permainan belajar bersikap. Ini dapat dilihat dari adanya perbedaan analisis pre test dan posttest yang tercermin dalam table dan histogram berikut: 
Tabel 4.5

Hasil Analisis Pre-test dan Post-test (Uji Wilxocon)

\begin{tabular}{|c|c|c|c|c|c|c|c|}
\hline \multirow[t]{2}{*}{ No. } & \multirow{2}{*}{$\begin{array}{c}\text { Nama } \\
\text { Responden }\end{array}$} & \multirow{2}{*}{$\begin{array}{c}\text { Pre- } \\
\text { test }\end{array}$} & \multirow{2}{*}{$\begin{array}{c}\begin{array}{r}\text { Post- } \\
\text { test }\end{array} \\
\text { Yi } \\
\end{array}$} & \multirow{2}{*}{$\begin{array}{c}\text { Beda } \\
\text { (Yi-Xi) }\end{array}$} & \multirow{2}{*}{$\begin{array}{c}\text { Peringkat } \\
\text { (Yi-Xi) }\end{array}$} & \multicolumn{2}{|c|}{$\begin{array}{c}\text { Tanda } \\
\text { Peringkat }\end{array}$} \\
\hline & & & & & & $(+)$ & $(-)$ \\
\hline 1 & $\mathrm{FZ}$ & 131 & 161 & +30 & 2 & 2 & \\
\hline 2 & MA & 121 & 148 & +27 & 5 & 5 & \\
\hline 3 & ESN & 128 & 144 & +16 & 7 & 7 & \\
\hline 4 & $\mathrm{ZR}$ & 122 & 150 & +28 & 4 & 4 & \\
\hline 5 & ACA & 117 & 146 & +29 & 3 & 3 & \\
\hline 6 & EA & 130 & 163 & +33 & 1 & 1 & \\
\hline 7 & $\mathrm{EE}$ & 128 & 143 & +15 & 8 & 8 & \\
\hline 8 & SDC & 123 & 147 & +24 & 6 & 6 & \\
\hline \multicolumn{6}{|c|}{ Jumlah } & 36 & 0 \\
\hline
\end{tabular}

Dari tabel di atas dapat diketahui bahwa nomor urut yang bertanda negatif $=$ “ 0 " sedangkan jumlah nomor urut yang bertanda positif $=36$, dengan demikian nomor urut dengan jumlah terkecil atau $\mathrm{T}=0$. Berdasarkan tabel nilai kritis $\mathrm{T}$ untuk uji jenjang Wilcoxon dengan taraf signifikan $5 \%$ dan $\mathrm{N}=8$ diperoleh $\mathrm{T}_{\text {tabel }}=4$ sehingga $\mathrm{T}_{\text {hitung }}$ lebih kecil $\mathrm{T}_{\text {tabel }}(0<4)$ berarti Ho ditolak dan Ha diterima, maka hipotesis yang diajukan dapat diterima yaitu terdapat perbedaan yang signifikan dalam skor penyesuaian diri sebelum dan sesudah penerapan bimbingan kelompok model permainan belajar bersikap pada siswa kelas VII Darul Ma’arif Payaman. 
Dari hasil pre test dan post test pada tabel di atas dapat digambarkan dalam grafik sebagai berikut :

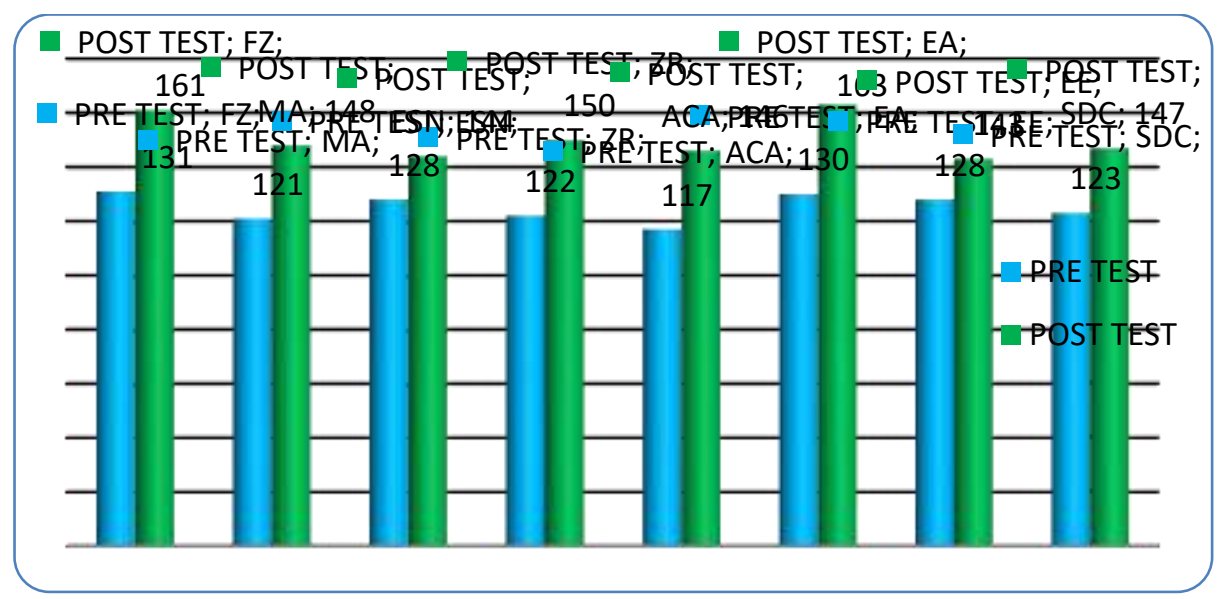

\section{Histrogram 4.3}

Hasil Analisis Pre Test dan Post Tes

\section{Penutup}

Berdasarkan penjelasan yang telah disampaikan sebelumnya, maka dapat diambil kesimpulan bahwa: hasil analisis data pre test dan post test menggunakan uji jenjang Wilxocson, diketahui bahwa nomor urut yang bertanda negatif = " 0 " sedangkan jumlah nomor urut yang bertanda positif $=36$, dengan demikian nomor urut dengan jumlah terkecil atau $\mathrm{T}=0$. Berdasarkan tabel nilai kritis $\mathrm{T}$ untuk uji jenjang Wilcoxon dengan taraf signifikan $5 \%$ dan $\mathrm{N}=8$ diperoleh $\mathrm{T}_{\text {tabel }}=4$ sehingga $\mathrm{T}_{\text {hitung }}$ lebih kecil $\mathrm{T}_{\text {tabel }}(0<4)$ berarti Ho ditolak dan Ha diterima, maka hipotesis yang diajukan dapat diterima yaitu terdapat perbedaan yang signifikan pada skor penyesuaian diri di sekolah sebelum dan sesudah penerapan bimbingan kelompok model permainan belajar bersikap pada siswa kelas VII MTs Darrul Ma’arif, Payaman, Lamongan. 


\section{Rujukan}

Panuju, Panut dan Ida Umami. 2005. Psikologi Remaja. Yogyakarta: Tiara Wacana

Sunarto dan Hartono Agung. 1999. Perkembangan Peserta Didik. Jakarta: Rieneka Cipta.

Tohirin. 2007. Bimbingan Dan Konseling Di Sekolah Dan Madrasah (Berbasis Integrasi). Jakarta: Raja Grafindo Persada

Willis, Sofyan. 2005. Remaja Dan Masalahnya. Bandung: Alfabeta.

Willis, Sofyan. 1994. Problem Remaja Dan Pemecahannya. Bandung: Angkasa.

Rumini, Sri dan Sundari Siti. 2004. Prekembangan Anak Dan Remaja. Jakarta: Rineka Cipta.

Nurihsan, Achmad Juntika. 2006. Bimbingan Dan Konseling Dalam Berbagai Latat Kehidupan. Bandung: Refika Aditama.

Nursalim, Mochamad dan Suradi. 2002. Layanan Bimbingna Dan Konseling. Surabaya: UNESA University Press.

Martini. 2005. "Prosedur dan Prinsip-prinsip Statistika”. Surabaya,Unesa University press

Siegel, Sidney. 1990. Statistik Non Parametrik Untuk Ilmu Sosial. Jakarta: Gramedia Pustaka Utama. 